\title{
ASSESSMENT OF GENETIC DIVERSITY AMONG TWO EGYPTIAN CATTLE POPULATIONS (Bos taurus) BASED ON AUTOSOMAL MICROSATELLITE MARKERS
}

\author{
M.A. El-Sayed ${ }^{1}$, A.Al-Soudy ${ }^{1}$ and Doaa, F. Teleb ${ }^{2}$ \\ 1- Animal Genetic Resources Department, National Gene Bank, Agricultural Research Center, Giza, \\ Egypt, 2- Sheep \& Goat Research Department, Animal Production Research Institute, Ministry of \\ Agriculture and Land Reclamation, Dokki, Giza, Egypt, \\ Correspondence to: Dr El-Sayed M. A., National Gene Bank, Agricultural Research Center, 9 Gamma St., \\ Giza, 12619, Egypt.Email: m.a.el_sayed@arc.sci.eg, m.a.el_sayed@outlook.com
}

\section{SUMMARY}

Two native cattle populations raised in Farafra and Siwa oases, located in the Western Desert of Egypt, were genotyped using eight microsatellite molecular markers (MM8, INRA063, BM1818, ILSTS054, ILSTS005, HEL5, ILSTSO06 and ILSTS011). Blood samples, collected from 38 individual cattle (19 from Farafra and 19 from Siwa), were subjected to DNA extraction and subsequently to SSR-PCR amplification. Heterozygosity and Wrights F-statistics (FIS, FST and FIT) were calculated to assess the genetic variation in these populations.

In the present study, high values of FIS were detected in Siwa (83\%) and Farafra (69\%) cattle with moderate genetic differentiation (13\%) between the two populations. A total number of 22 and 29 alleles with means $2.75 \pm 0.71$ and $3.63 \pm 0.74$ were observed in Siwa and Farafra cattle, respectively. Alleles observed per locus ranged between 2 (loci ILSTS054, ILSTS005 and ILSTS011) to 4 (locus HEL5) in Siwa cattle and between 3 (loci ILSTSO05, HEL5, ILSTSO06 and ILSTS011) to 5 (locus BM1818) in Farafra cattle populations. Mean values of observed and expected heterozygosities were 0.09 0.27 and0.46 \pm 0.21 for Siwa cattle, meanwhile it ranged from $0.20 \pm 0.35$ to $0.66 \pm 0.07$ in Farafra cattle. Polymorphic information content value (PIC) ranged from 0.10 to 0.71 for marker ILSTSO05 and HEL5, respectively, with a mean value of 0.45 for all loci in Siwa cattle. Moreover, its range was 0.52 (ILSTS054) to 0.74 (BM1818) for all loci with a mean of 0.64 in Farfra cattle. Population fixation indices traced about 0.653 variation referring to differences among individuals versus total variance (FIT), where it was the lowest among populations differences versus total variance (FST= 0.237 ) indicating low level of population differentiation. A pair-wise difference amongst Siwa and Farafra cattle populations was recorded (0.546) among populations (F index (FIS).Moreover, 4 and 11private alleles were observed in Siwa and Farafra cattle populations, respectively. Following that we are suggested the use of these alleles as population fingerprint and they could be used to differentiate these two populations.

Keywords: DNA microsatellite, genetic diversity, cattle, indigenous population

\section{INTRODUCTION}

In the recent years, rapid advanced development in molecular genetic techniques have made it possible to identify differences between individuals at the DNA level and using genomic variation for the genetic improvement of livestock. Molecular methods have provided new markers for the estimate of genetic variation, even to the level of analysis at the DNA sequences itself. Molecular markers have been widely used to assess this variability since they provide information on every region of the genome. Microsatellites (highly polymorphic simple sequences repeats) are the most widely used molecular markers. Genetic variability within and among populations is important and may contribute to the selection and preservation of genetic resources (Hassanane et al. 2006).

According to Food and Agriculture Organization (FAO, 1993) the Egyptian cattle consisted of eight breeds: two of them were disappeared or diminished (African aurochs and Hamitic longhorn) while the other six cattle breeds are Baladi, Domiette, Egyptian, Maryuti, Menufi, and Saidi, are still present (www.Fao.org). Local populations may have different names, but without apparent differences in phenotype; a change in phenotype may occur without change in name, or all populations may have just one name and be phenotypically similar. The Egyptian Baladi cattle are draft medium sized animals. Its color ranges from brown to black or pied. Due to the low milk productivity of these animals, it is neglected for a long time and its genetic improvement took place only through hybridization with exotic breeds (Morsy, 1980). Egypt is predominantly desert and arid or semi-arid rangelands which can be divided into four major physical regions; the Nile Valley and Delta, Western Desert, Eastern Desert and Sinai Peninsula (Figure 1). The new valley (El-Kharga, ElDakhla and El-Farafra) and Siwa oases located in the Western Deseret are especially for being geographically isolated regions. Accordingly, those 
oases have specific farm animal genetic resources (cattle- sheep- goat- camels) able to survive efficiently in the specific condition of these areas. Unique individuals of these animals need to be screened, evaluated and collected to maintain them as nucleus herds and to benefit them in sire centers. So, this study was aimed to assess the genetic diversity in the Egyptian native cattle raised in Siwa and ElFarafra Oasis (Figure 2 and 3) located in the Western desert by using microsatellite markers.

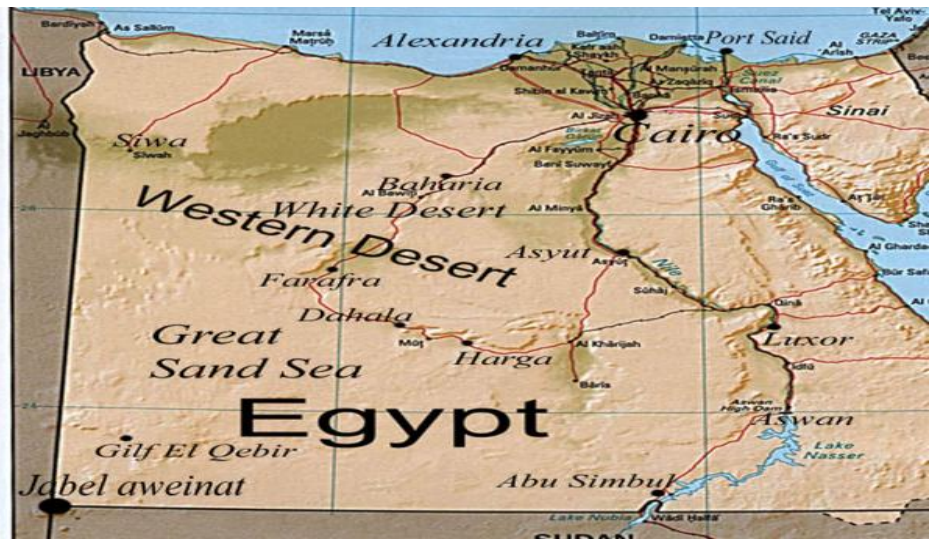

\section{Fig. 1: New valley (kharga, Dahala and Farafra) and Siwa oases.}

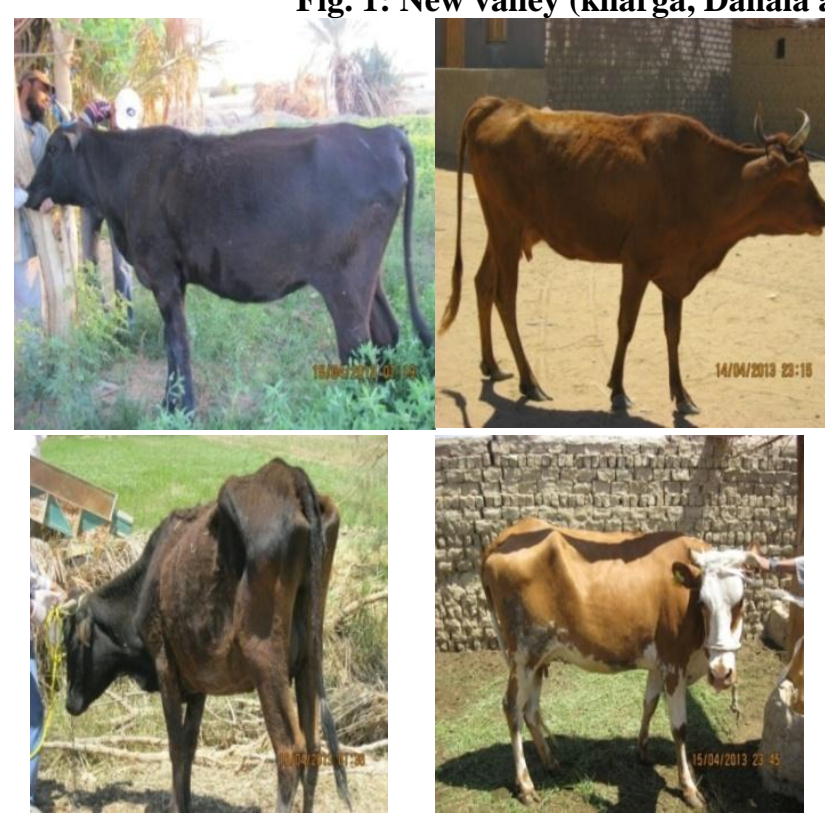

MATERIALS AND METHODS

According to the framework of the strategy of sustainable agriculture development (2030), this work was done throughout a project focused on sustainable utilization of agriculture biodiversity, development of agriculture products and improvement of rural livelihood, based on Integration of Genetic Resources Management (BIGRM) in Western Desert communities. The project targets four oases namely El-Kharga, El-Dakhla, El-Farafra and Siwa which have specific farm animal genetic resources (AnGR), adapted cultivars of alfalfa and a huge quantity of unused byproducts of dates palm, olive and other agriculture byproducts.

Cattle raised in Siwa and El- Farafra oases were genotyped using eight cattle microsatellites markers (MM8, INRA063, BM1818, ILSTS054, ILSTS005, HEL5, ILSTS006 and ILSTS011) as recommended by (FAO, 2004) and published papers (Pandey et al. 2006, Karthickeyan et al. 2008 and Sharma et al.
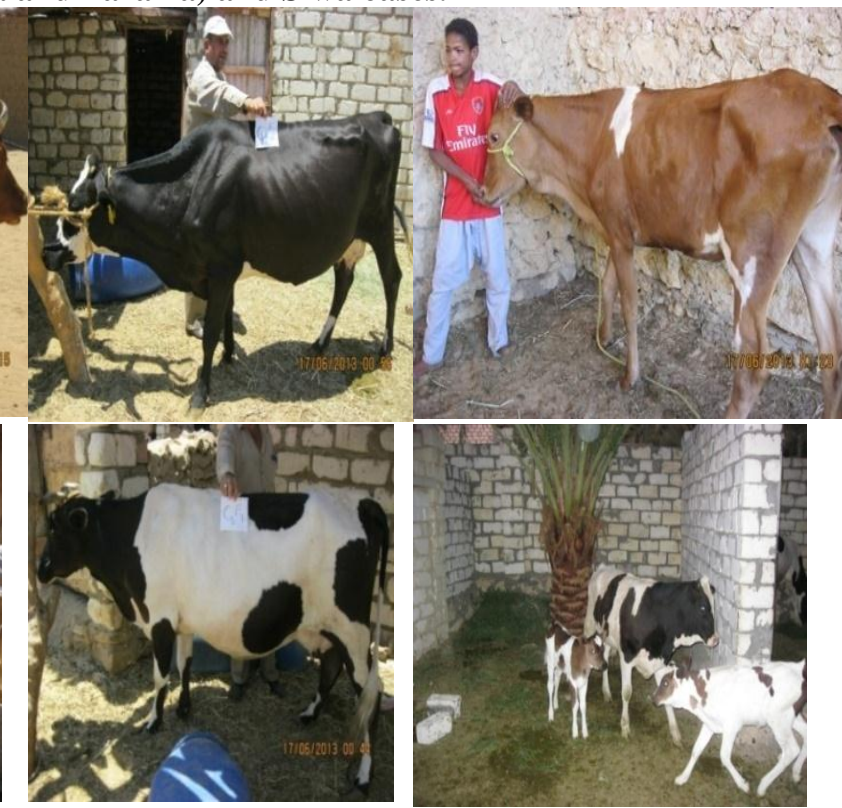

2015). The marker set distributed on 7 different autosomal chromosomes (2, 18, 23, 21, 10, 7 and 14, respectively). Microsatellite loci, accession number, Map, flanking sequences, chromosome number, repeat type, annealing temperature and allele range in base pairs are shown in table (1).

\section{Blood sample collection and DNA extraction}

Blood samples were collected from38cattle from different regions in Siwa $(n=19)$ and Farafra oases $(n=19)$. Genomic DNA extraction was carried out using the salting out method (Sambrook et al.1989).

\section{Microsatellite genotyping}

A set of eight microsatellite markers (Table 1), which have been recommended for cattle in FAO's Measurement of Domestic Animals Diversity (MoDAD) program(FAO,2004), were selected according to their degree of polymorphism and genome coverage (Pandey et al.,2006; Karthickeyan et al., 2008 and Sharma et al., 2015). 
Polymerase Chain Reaction (PCR) was performed using 50-100 ng genomic DNA in a $25 \mu$ reaction volume containing 10 $\mu$ l Master Mix (Emerald AMP GT PCR Master Mix, Takara Bio. Inc. composed of 10 pmol of each primer, DNA polymerase, optimized reaction buffer, dNTPs and a density reagent). The premix also contained a vivid green dye which is separate into blue and yellow dye fronts. The PCR reactions was carried out under the following conditions: an initial denaturation step (for $2 \mathrm{~min}$ at $95^{\circ} \mathrm{C}$ ), followed by 35 cycles of denaturation (for 30sat $95^{\circ} \mathrm{C}$ ); annealing (at $45-58^{\circ} \mathrm{Cfor} 60 \mathrm{~s}$ ) at optimized primer annealing temperature (Table 1). Then, extension (for $60 \mathrm{~s}$ at $72^{\circ} \mathrm{C}$ ) and final extension (for 60 sat $72^{\circ} \mathrm{C}$ ). Amplified fragments were analyzed on $10 \%$ polyacrylamide gel and stained with Ethidium bromide. The resultedgels were photographed and images were analyzed using Gel Documentation System (Alphaimager ${ }^{\mathrm{TM}}$ 2200, Cell Biosciences).

Table1. All information about the eight microsatellite markers used in this study, including locus name, accession number, Map, flanking sequences, chromosome number, repeat type, annealing temperature and allele range in base pairs

\begin{tabular}{|c|c|c|c|c|c|c|c|c|}
\hline $\begin{array}{l}\text { Locus } \\
\text { Name }\end{array}$ & $\begin{array}{c}\text { Accession } \\
\text { No }^{1}\end{array}$ & Map $^{1}$ & Forward primer ${ }^{1,2}$ & Reverse primer ${ }^{1,2}$ & Chr.No2 & $\begin{array}{c}\text { Repeat } \\
\text { type }^{1}\end{array}$ & $\mathbf{T a}^{2}$ & $\begin{array}{c}\text { Allele } \\
\text { range }^{2,3}\end{array}$ \\
\hline MM8 & -- & -- & CCCAAGGACAGAAAAGACT & CTCAAGATAAGACCACACC & 2 & (GT)11 & $55^{\circ} \mathrm{C}$ & $\begin{array}{l}114- \\
144\end{array}$ \\
\hline INRA063 & $\mathrm{X} 71507$ & M1 & ATTTGCACAAGCTAAATCTAACC & AAACCACAGAAATGCTTGGAAG & 18 & (AC) 13 & $\begin{array}{c}55- \\
58^{\circ} \mathrm{C}\end{array}$ & $\begin{array}{l}167- \\
189\end{array}$ \\
\hline BM1818 & G18391 & M19 & AGCTGGGAATATAACCAAAGG & AGTGCTTTCAAGGTCCATGC & 23 & (TG) 18 & $\begin{array}{c}56- \\
60^{\circ} \mathrm{C}\end{array}$ & $\begin{array}{l}248- \\
278\end{array}$ \\
\hline ILSTS054 & -- & -- & GAGGATCTTGATTTTGATGTCC & AGGGCCACTATGGTACTTCC & 21 & (TC) 19 & $55^{\circ} \mathrm{C}$ & $\begin{array}{l}132- \\
148\end{array}$ \\
\hline ILSTS005 & L23481 & M4 & GGAAGCAATGAAATCTATAGCC & TGTTCTGTGAGTTTGTAAGC & 10 & (AG) 16 & $\begin{array}{c}54- \\
58^{\circ} \mathrm{C}\end{array}$ & $\begin{array}{l}176- \\
194\end{array}$ \\
\hline HEL5 & X65204 & M5 & GCAGGATCACTTGTTAGGGA & AGACGTTAGTGTACATTAAC & 21 & (CT) 22 & $\begin{array}{c}52- \\
57^{\circ} \mathrm{C}\end{array}$ & $\begin{array}{l}145- \\
171\end{array}$ \\
\hline ILSTS006 & L23482 & M20 & TGTCTGTATTTCTGCTGTGG & ACACGGAAGCGATCTAAACG & 7 & (GT)23 & $55^{\circ} \mathrm{C}$ & $\begin{array}{l}277- \\
309\end{array}$ \\
\hline ILSTS011 & -- & -- & GCTTGCTACATGGAAAGTGC & CTAAAATGCAGAGCCCTACC & 14 & (CT) 15 & $58^{\circ} \mathrm{C}$ & $\begin{array}{l}249- \\
273\end{array}$ \\
\hline
\end{tabular}

1. Gene bank accession number; www.ncbi.nlm.nih.gov/. http://www.ncbi.nlm.nih.gov/genome/sts/sts.cgi?uid=280100

2. Annealing temperature, (FAO, 2004)

3. Published papers (Pandey et al., 2006, Karthickeyan et al., 2008 and Sharma et al., 2015)

\section{Statistical analysis}

All gels were visualized and scored with Alphaimages2200 software version 4.0.1 (Cell Biosciences). A Tandem Repeat Analyzer software package was adopted according to Benson (1999), to correct data for estimating the allele sizes according to number of repeats for each marker. Then, a spread sheet program (Microsoft Excel) was used to arrange the data for each population regarding each locus. Data was analyzed employing Arlequin 3.11 software package after data conversion using CONVERT program (Glaubitz, 2004). Number of alleles per locus (no), effective number of alleles (ENA), observed heterozygosity (Ho) and expected heterozygosity (He) were calculated to evaluate genetic variation within-breed. Moreover, withinpopulation inbreeding estimate (Wright's, 1978), known as, fixation index (FIS) at each microsatellite locus was estimated using the POPGENE, version 1.31(Yeh et al., 1999). The polymorphic information content (PIC) for each locus was also calculated according to Botstein et al. (1980).

\section{RESULTS AND DISCUSSION}

Allele size of the eight markers (MM8, INRA063, BM1818, ILSTS054, ILSTS005, HEL5, ILSTS006 and ILSTS011) ranged from 125-169bp, 163-215bp, 213-285bp, 110-167bp, 160-192bp, 127-193bp, 260$329 \mathrm{bp}$ and 240-270bp, respectively in Siwa and Farafra cattle populations (Table 2). Results agree with the selective standard of the microsatellite loci (the Secondary Guidelines for Development of
National Farm Animal Genetic Resources using reference Microsatellite given by FAO, 2004).In Gaolao and Kenkatha cattle, Chaudhari et al. (2009) found that allele size ranged from $118-150 \mathrm{bp}, 170$ 188bp, 258-280bp, 176-190bp, 279-301bp and260272bp with MM8, INRA063, BM1818, ILSTS005, ILSTS006 and ILSTS011, respectively. Gralak et al. (2004) reported that the size ranged from 262-264bp, 282bp with BM1818 and ILSTS006, respectively in European bison bovine. Meanwhile, Russell et al. (2000) recorded size range from 178-186bp and 149169bp with INRA063 and HEL5, respectively in Criollo cattle. Karthickeyan et al. (2008) found size range from 138-146bp, 180-186bp, 262-278bp, 132148bp, 182-194bp, 150-166bp, 290-300bp and 262274bp with MM8, INRA063, BM1818, ILSTS054, ILSTS005, HEL5, ILSTS006 and ILSTS011, respectively in Ongole cattle. In Indian cattle Kale et al. (2010) recorded size range from 151-167bp and 288-300bp with HEL5 and ILSTS006, respectively in Gir, Deoni and Kankrej breeds, while ranged from 114-144bp, 162-190bp, 137-195bp, 275-303bpand 249-273bp with MM8, INRA063, HEL5, ILSTS006 and ILSTS011, respectively in others Indian breed(Sharma et al. 2015). Ndiaye et al. (2015) reported size range from 194-206bp and 274-292bp with INRA063 and BM1818, respectively in Senegalese cattle breeds. Agung et al. (2016) observed size range from 248-278bp and 277-309bp with BM1818 and ILSTS006in Indonesian cattle breeds. 
Table2. Allele size range (bp) observed, number of alleles (no, observed; ENA effective) and heterozygosis (HO, observed; He, expected) for eight microsatellite loci in Siwa and Farafra cattle populations

\begin{tabular}{|c|c|c|c|c|c|c|c|c|c|c|}
\hline \multirow{2}{*}{\multicolumn{3}{|c|}{ Allele size range }} & \multicolumn{4}{|c|}{ Number of alleles } & \multicolumn{4}{|c|}{ Heterozygosis } \\
\hline & & & \multicolumn{2}{|c|}{ Siwa } & \multicolumn{2}{|c|}{ Farafra } & \multicolumn{2}{|c|}{ Siwa } & \multicolumn{2}{|c|}{ Farafra } \\
\hline locus & Siwa & Farafra & no & ENA & no & ENA & $\mathrm{HO}$ & $\mathrm{He}$ & $\mathrm{HO}$ & $\mathrm{He}$ \\
\hline MM8 & $147-169$ & $125-158$ & 3 & 2.65 & 4 & 3.25 & 0.00 & 0.64 & 0.00 & 0.71 \\
\hline INRA063 & $163-189$ & $176-215$ & 3 & 1.97 & 4 & 2.26 & 0.00 & 0.51 & 0.11 & 0.57 \\
\hline BM1818 & $249-285$ & $213-285$ & 3 & 2.11 & 5 & 3.72 & 0.00 & 0.54 & 0.00 & 0.75 \\
\hline ILSTS054 & $148-167$ & $110-167$ & 2 & 1.44 & 4 & 2.05 & 0.00 & 0.31 & 0.00 & 0.53 \\
\hline ILSTS005 & $160-176$ & $160-192$ & 2 & 1.11 & 3 & 2.89 & 0.00 & 0.10 & 0.68 & 0.67 \\
\hline HEL5 & $127-193$ & $127-171$ & 4 & 3.46 & 3 & 2.98 & 0.00 & 0.73 & 0.00 & 0.68 \\
\hline ILSTS006 & 283-329 & $260-306$ & 3 & 2.16 & 3 & 2.88 & 0.75 & 0.55 & 0.84 & 0.67 \\
\hline ILSTS011 & $255-270$ & $240-270$ & 2 & 1.38 & 3 & 2.77 & 0.00 & 0.29 & 0.00 & 0.65 \\
\hline Mean & & & 2.75 & 2.04 & 3.63 & 2.85 & 0.09 & 0.46 & 0.20 & 0.66 \\
\hline SD & & & 0.71 & 0.76 & 0.74 & 0.52 & 0.27 & 0.21 & 0.35 & 0.07 \\
\hline IC & & & & & & & \multicolumn{2}{|c|}{0.80} & \multicolumn{2}{|c|}{0.70} \\
\hline \multicolumn{11}{|c|}{$\begin{array}{l}\text { no: Observed number of alleles } \\
\text { IC: inbreeding coefficient. }(\mathrm{IC}=(\mathrm{HE}-\mathrm{HO}) / \mathrm{HE})\end{array}$} \\
\hline \multirow[b]{2}{*}{ locus } & \multicolumn{3}{|c|}{ PIC } & \multicolumn{3}{|c|}{ FIS } & \multicolumn{4}{|c|}{ F-Statistics } \\
\hline & Siwa & Farafra & Mean & Siwa & & cafra & FIS & FIT & & FST \\
\hline MM8 & 0.62 & 0.69 & 0.66 & 1.00 & & & 1.00 & 1.00 & & 0.16 \\
\hline INRA063 & 0.49 & 0.55 & 0.52 & 1.00 & & & 0.90 & 0.91 & & 0.08 \\
\hline BM1818 & 0.53 & 0.74 & 0.64 & 1.00 & & & 1.00 & 1.00 & & 0.17 \\
\hline ILSTS054 & 0.31 & 0.52 & 0.42 & 1.00 & & & 1.00 & 1.00 & & 0.05 \\
\hline ILSTS005 & 0.10 & 0.65 & 0.38 & 1.00 & & & 0.09 & 0.38 & & 0.32 \\
\hline HEL5 & 0.71 & 0.66 & 0.69 & 1.00 & & & 1.00 & 1.00 & & 0.03 \\
\hline ILSTS006 & 0.53 & 0.65 & 0.59 & -0.37 & & & -0.34 & -0.17 & & 0.13 \\
\hline ILSTS011 & 0.28 & 0.63 & 0.46 & 1.00 & & & 1.00 & 1.00 & & 0.10 \\
\hline Mean & 0.45 & 0.64 & 0.55 & 0.83 & & & 0.73 & 0.76 & & 0.13 \\
\hline
\end{tabular}

Population specific FIS indices per polymorphic locus (absolute values)

Table4. AMOVA analysis of Farafra and Siwa cattle populations based on microsatellite DNA variation.

\begin{tabular}{lllll}
\hline Source of variation & d.f. & S .S. & $\begin{array}{l}\text { Percentage of } \\
\text { variation }\end{array}$ & Fixation indices \\
\hline $\begin{array}{l}\text { Among populations } \\
\begin{array}{l}\text { Among individuals } \\
\text { populations }\end{array}\end{array}$ & 1 & 16.58 & 23.65 & FIS=0.5455 \\
$\begin{array}{l}\text { Within individuals } \\
\text { Total }\end{array}$ & 36 & 69.26 & 41.65 & FST $=0.2365$ \\
\hline
\end{tabular}

FIS: Fixation indices (Among populations)

FST: Fixation indices (Among individuals within populations)

FIT: Fixation indices (Within individuals) 
Table5. Allele size in base pairs, their frequencies for each locus and population and average of allele frequencies as observed in the present study

\begin{tabular}{llllllll}
\hline Locus & $\begin{array}{l}\text { Alleles } \\
\text { (bp) }\end{array}$ & \multicolumn{2}{l}{ Frequencies } & Locus & $\begin{array}{c}\text { Alleles } \\
\text { (bp) }\end{array}$ & \multicolumn{2}{l}{ Frequencies } \\
\hline \multirow{3}{*}{ MM8 } & & Siwa & Farafra & & & Siwa & Farafra \\
& 125 & 0.00 & 0.35 & INRA063 & 163 & 0.29 & 0.00 \\
& 136 & 0.00 & 0.24 & & 176 & 0.06 & 0.08 \\
& 147 & 0.18 & 0.35 & & 189 & 0.65 & 0.58 \\
Average & 158 & 0.47 & 0.06 & & 202 & 0.00 & 0.32 \\
& 169 & 0.35 & 0.00 & & 215 & 0.00 & 0.02 \\
& -- & $\mathbf{0 . 3 3}$ & $\mathbf{0 . 2 5}$ & Average & -- & $\mathbf{0 . 3 3}$ & $\mathbf{0 . 2 5}$ \\
BM1818 & 213 & 0.00 & 0.36 & ILSTS054 & 110 & 0.00 & 0.11 \\
& 231 & 0.00 & 0.31 & & 129 & 0.00 & 0.17 \\
& 249 & 0.06 & 0.11 & & 148 & 0.81 & 0.66 \\
Average & 267 & 0.59 & 0.11 & & 167 & 0.19 & 0.06 \\
ILSTS005 & 285 & 0.35 & 0.11 & & & & \\
& -- & $\mathbf{0 . 3 3}$ & $\mathbf{0 . 2 0}$ & Average & - & $\mathbf{0 . 5 0}$ & $\mathbf{0 . 2 5}$ \\
& 160 & 0.05 & 0.42 & HEL5 & 127 & 0.31 & 0.29 \\
Average & 176 & 0.95 & 0.26 & & 149 & 0.13 & 0.36 \\
ILSTS006 & 192 & 0.00 & 0.32 & & 171 & 0.37 & 0.35 \\
& -- & & & & 193 & 0.19 & 0.00 \\
& 260 & 0.00 & 0.37 & ILSTS011 & 240 & 0.00 & 0.26 \\
& 283 & 0.63 & 0.24 & & 255 & 0.17 & 0.26 \\
Average & 306 & 0.22 & 0.39 & & 270 & 0.83 & 0.48 \\
\hline
\end{tabular}

A total number of 22 and 29 alleles with mean values of $2.75 \pm 0.71$ and $3.63 \pm 0.74$ were observed in Siwa and Farafra cattle, respectively (Table 2). Alleles observed per locus ranged between 2 (loci ILSTS054, ILSTS005 and ILSTS011) to4 (locus HEL5) in Siwa cattle and between 3(loci ILSTS005, HEL5, ILSTS006 and ILSTS011) to5 (locus BM1818) in Farafra cattle population (Table 2). The mean numbers of alleles observed in the investigated populations was slightly lower than those reported by other authors. Pandey et al. (2006) recorded that the number of observed alleles varied between 3 (ILSTS011) to 10 (ILSTS034) with an overall mean number of 5.95 \pm 1.9 alleles per locus. Chaudhari et al. (2009) observed a total of 239 and 197 distinct alleles with mean values of 9.52 and 7.92 in Gaolao and Kenkatha cattle, respectively. They also, reported that alleles observed per locus ranged between 5 (loci ILSTS006 and ILSTS030) and 15 (locus ILSTS034) and between 4 (locus ILSTS006) and 14 (loci BM1824 and ILSTS006) in Gaolao and Kenkatha cattle, respectively. A total of 74 alleles were detected across the 9 loci with an average of 7, 5 and 5 alleles per locus in Fuga, Butana and Kenana breeds, respectively (Hussein et al. 2014). Moreover, they recorded a total of 359 alleles with (ILSTS34), which represent the highest number of alleles per locus (37), while (CSSM08) was the lowest polymorphic alleles (8). Sharma et al. (2015) reported an average number of alleles per locus to be $6.571 \pm 0.732$ and $10.619 \pm 0.824$ in Hariana and Shahabadi cattle, respectively with a mean number of allele across all the loci $8.784 \pm 0.25$ and average number 10.45 allele per locus. The observed number of alleles per locus (Na) varied from 6 in INRA063 to 16 in TGLA53 in Senegal cattle (Ndiaye et al. 2015). Agung et al (2016) detect 317, 143 and 91 alleles in Simmental purebred, Simmental Cross Ongole Grade (PO), respectively using 12 microsatellites. They suggested that the lower values of expected number of alleles compared to the observed may be due to several low allele frequencies in the populations.

Effective number of alleles (ENA) is a reciprocal of gene homozygosity (Hartl and Clark, 1997) and it is used to corollary the HE (when heterozygosity is high ENA will be the highest). In Siwa cattle, the lowest ENA was 1.11 for (ILSTS005) when HE was 0.10, while the highest ENA was 3.46 for (HEL5) when $\mathrm{HE}$ was 0.73 (Table 2).Moreover, the lowest ENA was 2.05 for (ILSTS054) when HE was 0.53, while the highest ENA was 3.72 for (BM1818) when HE was 0.75 in Farafra cattle. The mean effective number of alleles varied from $2.04 \pm 0.76$ to $2.85 \pm$ 0.52in Siwa and Farafra population (Table 2).Averages of effective number of alleles in the present study was lower than that reported by Sharma et al. (2015) whose observed that averages effective number of alleles within one population varied from $3.374 \pm 0.329$ to $4.745 \pm 0.532$ in Hariana and Shahabadi cattle, respectively. Also, Ndiaye et al (2015) reported a mean effective number of alleles per population of $4.48 \pm 0.21$ in four local cattle breeds (Gobra zebu, Maure zebu, Djakoré, and N'Dama) of Senegal.

Results showed that the observed heterozygosity (Ho) in Siwa cattle ranged between 0.00(loci MM8, 
INRA063, BM1818, ILSTS054, ILSTS005, HEL5 and ILSTS011) to 0.75 (locus ILSTS006), while it was between 0.00 (loci MM8, BM1818, ILSTS054, HEL5 and ILSTS011) to 0.84 (ILSTS006) in Farafra cattle population(Table 2).Moreover, expected heterozygosity $(\mathrm{He})$ ranged between 0.10 (ILSTS005) to 0.73 (HEL5) in Siwa and between 0.53 (ILSTS054) to 0.75 (BM1818) in Farafra cattle population. The mean values of the expected heterozygosity were $0.46 \pm 0.21$ and $0.66 \pm 0.07$ in Siwaand Farafra cattle populations, respectively (Table 2). Gralak et al. (2004) recordedan expected heterozygosity (He) ranged from 0.13 (HEL9) to 0.53 (ETH3). Pandey et al. (2006) reported that the averaged of observed heterozygosity was $0.540 \pm 0.171$ over the 21 loci, while the average of expected heterozygosity ranged from 0.530 (ETH225) to 0.825 (INRA035) with an overall mean of $0.685 \pm 0.100$ in Kenkatha population. Moreover, Chaudhari et al (2009) recorded that the observed heterozygosity (Ho) ranged between 0.014 (ILSTS006) to 0.7800 (ILSTS034) in Kenkatha and between 0.1000 (ILSTS006) to 0.7500 (ILSTS030) in Gaolao cattle, while the expected heterozygosity $(\mathrm{He})$ ranged between 0.1523 (ETH3) to 0.8881 (ILSTS034) in Kenkatha and between 0.3330 (ETH152) to 0.9029 (ILSIS034) in Gaolao cattle. They also reported that the means values of observed and expected heterozygosities were $0.47 \pm 0.24$ and $0.62 \pm 0.21$, respectively in Kenkatha and $0.53 \pm 0.17$ and $0.68 \pm 0.14$, respectively in Gaolao cattle.Hussein et al (2014) reported an observed mean (Ho) and expected heterozygosity (He) of 0.778 and 0.725 in Fuga vs. 0.737; 0.695 in Butana and $0.693 ; 0.651$ in Kenana cattle, respectively. Among populations, observed heterozygosity ranged from $0.459 \pm 0.07$ to $0.724 \pm 0.036$ with the lowest value found in Ongole cattle and the highest in Kenkatha cattle, while the observed heterozygosity was lower than the expected heterozygosity in Bachaur, Ponwar, Shahabadi, Purnea, Mewati, Gaolao, Hariana and Ongole cattle populations (Sharma et al., 2015). Ndiaye et al. (2015) reported that all loci showed high levels of heterozygosity $(>0.60)$, except for INRA063, which generated Ho and He values of 0.44 and 0.60 , respectively. The slight difference between the mean observed compared to the expected heterozygosity detected in the present study may reflect slight inbreeding/ and or crossbreed and selection against heterozygotes. Moreover, the nature of the markers used may also contribute to the observed level of heterozygosity as a result of non-detection of homozygotes from heterozygotes due to presence of null alleles.

The mean value of FIS obtained for Siwa cattle (0.83) indicate high level of inbreeding within this population, which confirmed by IC $(0.80)$, while the mean value for Farafra cattle (0.69)reflect high variability in these population confirmed by inbreeding coefficient 0.70 (Table 2 and 3). These findings might be due to more recent divergence of Farafra cattle than Siwa cattle one.
The value of the Polymorphic information content (PIC) for Siwa cattle ranged from 0.10 to 0.71 inILSTS005and HEL5, respectively with a mean of 0.45 for all loci (Table 3). Mean while, it ranged from 0.52 to 0.74 for inILSTS054and BM1818, respectively with a mean of 0.64 for Farafra cattle (Table 3). These differences reflect high genetic variability within Farafra population. The majority of the microsatellite loci used in this study was highly revealing (Table 3). According to classification of Botstein et al. (1980), the highly informative markers have PIC values $>0.50$, the reasonably informative markers have PIC value between $0.25-0.50$ and the slightly informative markers have PIC value $<0.25$. In the present study, three markers (ILSTS054, ILSTS005 and ILSTS011) had reasonably informative PIC values of $0.42,0.38$ and 0.46 , respectively, while the majority of the loci were highly informative. Similarly, Chaudhari et al. (2009)found that all other loci possessed a high PIC value (> 0.5) except six loci (BM1824, ETH3, ETH152, HEL51, ILSTS005 and ILSTS006) in Kenkatha and five loci (BM1824, CSRM60, ETH152, ILSTS005 and ILSTS006) in Gaolao cattle.PIC values varied from 0.304 (ETH225) to 0.793 (BMC3113) in Kenana and Fuga breed with a mean of $0.664,0.630$ and 0.596 in Fuga, Butana and Kenana cattle, respectively (Hussein et al., 2014). Moreover, Ndiaye et al. (2015) reported that Gobra zebu had the highest PIC value (0.75), while N'Dama had the lowest value (0.66). Results of the present study showed that the markers used are highly informative for characterization of both cattle populations.

The within-population inbreeding estimate (FIS) was 0.83and 0.69in Siwa and Farafra cattle, respectively (Table 2).The FIS used to obtain a deeper insight to appraise the degree of inbreeding and endangerment potentiality, it is considered as an important tool to judge the conservation priority (Simon and Bchenauer, 1993). Accordingly, when FIS is less than 0.05, the breeds are not in danger; between $0.05-0.15$, they are potentially endangered; between $0.15-0.25$, they are minimally endangered; between $0.25-0.40$, they are endangered; and more than 0.40 , they are critically endangered. Pandey et al. (2006) found that (FIS) estimates ranged between $-0.179-0.572$ with an average of 0.214 and an average deficiency $(21.4 \%)$ of heterozygote existed in the Kenkatha population. The within-population inbreeding estimate (FIS) was 0.2121 and 0.2248in Gaolao and Kenkatha cattle, respectively (Chaudhari et al., 2009).Hussein et al. (2014) observed that the lowest value of FIS in Butana (-0.830) as compared with Kenana and Fuga cattle (-0.195 and -0.317, respectively).Moreover, Sharma et al. (2015) observed significant heterozygote deficit in eight out of 12 investigated breeds being highest in Ongole (0.221).

Mean values of FIS, FIT and FST were 0.73, 0.76 and 0.13 , respectively (Table 2 ). High values of heterozygosities were observed in Siwa and Farafra 
populations (83 and $69 \%$, respectively), while a moderate genetic differentiation (13\%) was observed between the two populations. Chaudhari et al. (2009) reported that the mean FIS, FIT and FST values were $0.2318,0.2487$ and 0.0219 with a substantial deficit of heterozygotes $21.21 \%$ and $22.48 \%$, in Gaolao and Kenkatha cattle populations, respectively. They also, recorded a little genetic differentiation (2.19\%) between the two breeds. Moreover, Sharma et al. (2015) observed a substantial deficit $(4.9 \%$ and 17.5 $\%$ ) of heterozygotes in cattle populations with a moderate genetic differentiation $(13.3 \%)$ between the two breeds of Indian cattle.

Results of the AMOVA analysis are represented in Table (4). Results showed that the majority of the genetic diversity obtained in the current study is presented by among individuals within populations $(41.65 \%)$ and within individuals (34.70\%). Population fixation indices give an idea about the population structure in terms of inbreeding coefficient and population differentiation. Population Fixation indices revealed a 0.653 of variation referring to differences among individuals versus total variance (Fit). While, among populations differences versus total variance was the lowest fixation index $(F s t=0.237)$ indicating low level of population differentiation. A pair wise difference among Frafra and Siwa cattle populations was 0.546 based on among breeds $F$ index (Fis) as shown in Table (4). Sharma et al. (2015) reported that AMOVA revealed that percent of variation among populations was $24 \%$, while it was $76 \%$ within populations.

In Siwa cattle, fourout of the 22 alleles were private alleles (locus MM8, ILSTS006, INRA063 and HEL5); while in Farafra cattle 11out of the 29 alleles were detected as private alleles (locus MM8, INRA063, BM1818, ILSTS054, ILSTS005, ILSTS006 and ILSTS011). Regarding specific alleles, a total number of 15 out of 51 alleles $(29.41 \%)$ were noticed overall loci for the two studied populations as shown in Table (5). Consequently, those private alleles would be utilized as population fingerprint (even one allele for one locus) and could be used to differentiate between the two populations. Russell et al. (2000) detected the 145-bp allele in Chinipas cattle, which was absent in cattle raised in others regions. Gralak et al. (2004) observed two alleles (74 bp at the monomorphic locus TGLA227 and 89 bp at locus CSRM60), which seem to be specific for the European bison. Moreover, Chaudhari et al. (2009) reported that 14 out of the 239 alleles were private alleles (locus ETH10, ETH152, HEL51, ILSTS005, ILSTS006, ILSTS0554, INRA005, MM8, HAUT24) in Gaolao cattle, while 6 out of 197 alleles were recorded (locus CSRM60, ETH185, HAUT27, INRA063 in Kenkatha cattle.

In the present study, the highest allele frequency overall loci was 0.95 for allele 176 at ILSTS005 locus in Siwa population, while the lowest one (0.05) was for allele 160 at the same locus. In addition, the highest average of allele frequency estimated was at HEL5 (0.50), ILSTS005 (0.50) and ILSTS011 (0.50). In Farafra cattle population, the lowest one (0.20) was at BM1818. Russell et al. (2000) detected five alleles at INRA063 in the cattle from the Temoris regionthat contained a specific allele (184 bp) with a frequency of 0.14 . They also recorded another unique allele frequency (186-bp), with a higher representation among the Chinipas samples (0.42) than among samples from different regions (0.06 to 0.18) HEL5at locus. Furthermore, allele frequencies were the greatest in cattle from all regions for the 151- and 163-bp alleles, excluding cattle from Temoris, which had allele frequencies of 0.25 at 149 and $167 \mathrm{bp}$ alleles.

\section{CONCLUSION}

The present investigation proved the usefulness of using eight microsatellite markers to discriminate cattle raised in Siwa and Farafra oases. Four out of twenty-two alleles were detected as private alleles (locus MM8, ILSTS006, INRA063 and HEL5) in Siwa cattle, while 11 out of 29 private alleles were observed in Farafra cattle (locus MM8, INRA063, BM1818, ILSTS054, ILSTS005, ILSTS006 and ILSTS011). Regarding the specific alleles, a total of 15 out of 51 alleles $(29.41 \%)$ were noticed overall the loci for the two studied populations. Results confirmed that microsatellite markers could be strongly utilized as a molecular tool in fingerprint analysis for Farafra and Siwa cattle populations. High heterozygotes (83\% and 69\%) were detected in Siwa and Farafra cattle populations, respectively with a moderate genetic differentiation $(13 \%)$ between the two populations. The present work suggested using wide genome scan analysis based on more recommended microsatellites covering cattle genome, which could be utilized in further work concerning MAS (marker assisted selection) and QTL (Quantitative Trait Loci) programs. Moreover, further studies are recommended for more details about Siwa and Farafra cattle population.

\section{ACKNOWLEDGEMENTS}

This work was part of a project (No: 176-A) funded by the Agricultural Development Program (ADP).

\section{REFERENCES}

Agung P.P., F.Saputra, W.A. Septian, Lusiana, M. S. A. Zein, S. Sulandari, S. Anwar, A.. Wulandari, S. Said, and B. Tappa 2016. Study of Genetic Diversity among Simmental Cross Cattle in West Sumatra Based on Microsatellite Markers. Asian Australas. J. Anim. Sci. 29 (2): 176-183.

Benson G., 1999. Tandem Repeat Finder.a program to analysis DNA sequences. Nucleic Acides Research.27 (2):573-580. 
Botstein, D., White, R. L., Skolnick, M. \& Davis R. W., 1980. Construction of a genetic linkage map in man using restriction fragment length polymorphism. Am. J. Hum. Genet. , 32: 324 331.

Chaudhari M. V., S. N. S. Parmar, C. G. Joshi, C. D. Bhong, S. Fatima, M. S. Thakur and S. S. Thakur 2009. Molecular characterization of Kenkatha and Gaolao (Bos indicus) cattle breeds using microsatellite markers Animal Biodiversity and Conservation.32.2.

FAO, 1993. Food and Agriculture Organization of the United Nations, Rome. Breed database, Map Manager, http://dad.fao.org/en/Home.htm.

FAO, 2004. Secondary guidelines for development of national farm animal genetic resources management plans. Measurement of domestic animal diversity (MoDAD): Recommended microsatellite markers, Rome., Italy. FAO: www.dad.fao.org/en/ refer/library/guidelin/marker.pdf).

Glaubitz J.C., 2004. Convert: a user friendly program to reformate diploid genotypic data for commonly used population genetic software package. Molecular Ecology Notes 4:309-310.

Gralak B., M.Krasiñska, C. Niemczewski, A. Krasiñski and M. Urkowski 2004. Polymorphism of bovine microsatellite DNA sequences in the lowland European bison. Acta Theriologica 49 (4): 449-456, PL ISSN 0001-7051.

Hartl D.L., Clark A.G. 1997. Principles of Population Genetics 3rd ed., Sinauer Associates, Inc., Sunderland, MA, USA.

Hassanane M. S., H. M. El-Ashmaoui, S. Abd ElBaset, M.M. S. Mabrouk and Z. G. AbdelHameid 2006. Preliminary results on genetic diversity in Egyptian cattle using microsatellite markers. Egyptian J. Anim. Prod., 43(1):11-24.

Hussein I. H., S. S Alam, A.A. Makkawi, S.A.SidAhmed, A. S Abdoon, M. S. Hassanane 2014. Genetic Diversity Between and Within Sudanese Zebu Cattle Breeds Using microsatellite Markers. Research Article. In press.

Kale D S, D N Rank, C G Joshi, B R Yadav, P G Koringa, K M Thakkar, T C Tolenkhomba and J V Solanki 2010. Genetic diversity among Indian Gir, Deoni and Kankrej cattle breeds based on microsatellite markers. Indian Journal of Biotechnology.9: 126-130.

KarthickeyanS.M.K.,P.Kumarasamy,S.N.Sivaselvam ,R.Saravana and P. Thangaraju 2008. Analysis of microsatellite markers in ongole breed of cattle.indian jornal of biotechnology. 7:113-116.

Morsy, M. A., 1980. Dairy cattle management. Cairo University publishing.

Ndiaye N.P., A.Sow, G.K. Dayo, S.Ndiaye, G.J.Sawadogo and M.Sembène 2015. Genetic diversity and phylogenetic relationships in local cattle breeds of Senegal based on autosomal microsatellite markers. Veterinary World, EISSN: 2231-0916, Available www.veterinaryworld.org/Vol.8/August2015/9.pdf.

Pandey A. K., R.Sharma, Y. Singh, B. Prakash and S. P. S. Ahlawat 2006. Evaluation of Genetic Variability in Kenkatha Cattle by Microsatellite Markers. Asian-Aust. J. Anim. Sci. 19 (12): 1685 $-1690$.

Pandey A. K., Rekha Sharma, Yatender Singh, B. Prakash and S. P. S. Ahlawat 2006. Evaluation of Genetic Variability in Kenkatha Cattle by Microsatellite Markers. Asian-Aust. J. Anim. Sci.19 (12) : $1685-1690$.

Russell N. D., J. Rios, G. Erosa, M. D. Remmenga, and D. E. Hawkins 2000. Genetic differentiation among geographically isolated populations of Criollo cattle and their divergence from other Bos taurus breeds. J. Anim. Sci. 2000. 78:2314-2322.

Sambrook, J.; Fritsch, E. F. and Maniatis, T. 1989. Molecular Cloning - A Laboratory Manual, Cold Spring Harbor Laboratory, Press.

Sharma R., A.Kishore, M.Mukesh, S. Ahlawat, A. Maitra, A. K. Pandey and M. S.Tantia 2015. Genetic diversity and relationship of Indian cattle inferred from microsatellite and mitochondrial DNA markers. BMC Genetics 16:73, DOI 10.1186/s12863-015-0221-0.

Simon, D.L. and Buchenauer, D. 1993. Genetic diversity of European livestock breeds. Results of Moni-toring by the EAAP Working Group on Animal Genetic Resources; EAAP Animal Genetic Data Bank, Institute of Animal Breeding and Genetics, School of Veterinary Medicine, Hannover, EAAP Publication, No. 66, Wageningen Pers, Wageningen, 591 .

Wright, S., 1978. Variability within and among natural populations. The Univ. of Chicago Press, Chicago.

Yeh, F.C., Boyle, T., Rongcai, Y., Ye, Z., Xian, J.M. 1999. POPGENE, Version 1.31. A Microsoft Window Based Freeware for Population Genetic Analysis. University of Alberta, Edmonton. 
دراسة التتوع الوراثى بين مجموعتين من الأبقار المصرية بإستخذام بعض الواسمات الجزيئية الجسدية

محمد احمد السيد'، ،السيد السعودى' ،دعاء طلب

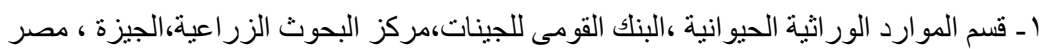

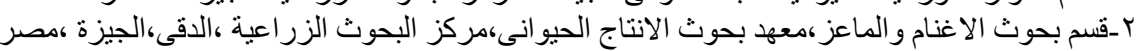

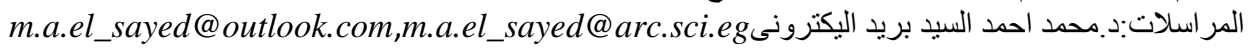

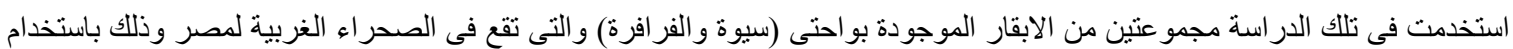

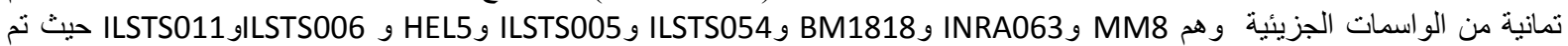

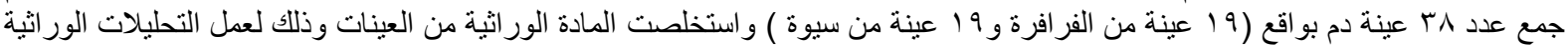

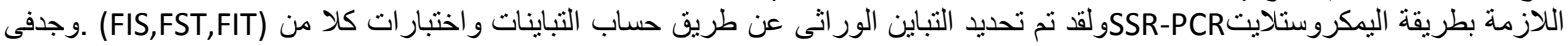

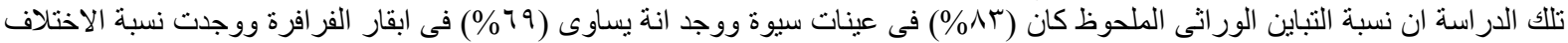

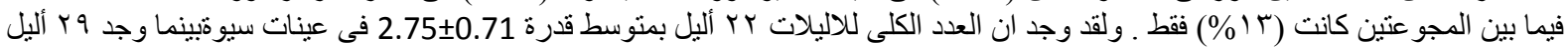

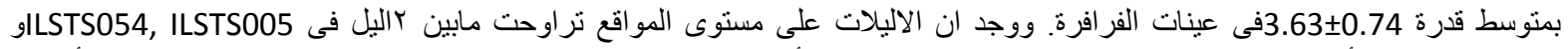

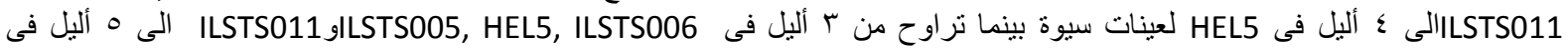

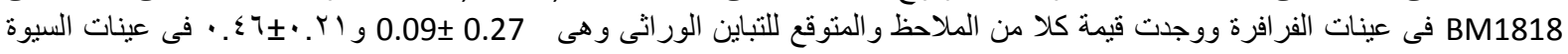

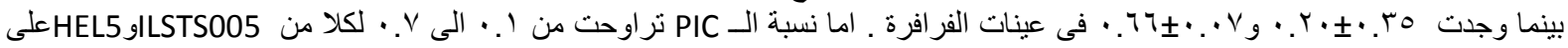

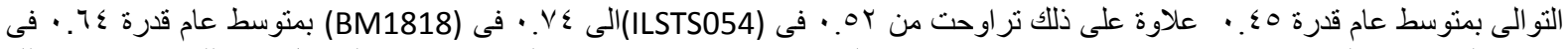

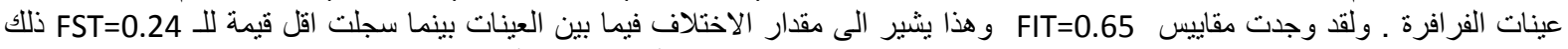
دليل على الاختلافات القليلة مابين المجمو عتين بينما سجلت

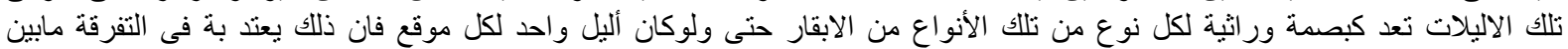
المجمو عتين من الابقار. 